\title{
Acholeplasma parvum, a New Species from Horses
}

\author{
HISAE ATOBE, JUNKO WATABE, AND MANABU OGATA* \\ Department of Veterinary Microbiology, Faculty of Agriculture, University of Tokyo, Bunkyo-ku, Tokyo 113, \\ Japan
}

Four glucose-nonfermenting Acholeplasma strains were isolated from oral cavities of horses and a horse vagina. The biological and serological properties of these isolates were distinct from those of the eight currently recognized Acholeplasma species. These strains were regarded as belonging to a new species, which was given the name Acholeplasma parvum. Strain H23M was designated the type strain of $A$. parvum, and a culture of this strain has been deposited in the American Type Culture Collection as strain ATCC 29892.

Previously, we reported $(14,24)$ the isolation of four strains of Acholeplasma from horses; these strains differed from the previously described species of Acholeplasma by lacking the ability to ferment glucose. This study was undertaken to determine whether these strains constitute a new species.

\section{MATERIALS AND METHODS}

Bacterial strains. Strains $\mathrm{H} 7 \mathrm{M}, \mathrm{H} 15 \mathrm{M}$, and $\mathrm{H} 23 \mathrm{M}^{\mathrm{T}}$ (type strain) were isolated from the oral cavities of healthy horses, and strain $\mathrm{H} 23 \mathrm{~V}$ was isolated from the vagina of a healthy horse. Each strain was purified by picking growth from a well-isolated single colony, inoculating this growth into broth, and, after 4 days of incubation, filtering the resulting broth culture through a 450-nm filter; the filtrate was plated onto a solid medium to obtain isolated colonies. This procedure was repeated at least three times (21). The following type strains of Acholeplasma and Mycoplasma species were used for comparative purposes: Acholeplasma laidlawii PG8 (= ATCC 23206), Mycoplasma arthritidis PG6 (= ATCC 19611), and Mycoplasma bovigenitalium PG11 (= ATCC 19852), which were obtained from D. G. ff. Edward, Wellcome Research Laboratories, Beckenham, Kent, England; Acholeplasma granularum BTS39 (= ATCC 19168), obtained from W. P. Switzer, Iowa State University Veterinary Medical Research Institute, Ames, Iowa; Acholeplasma axanthum S743 (= ATCC 25176) and Acholeplasma morum 72-043 (= ATCC 33211) obtained from J. G. Tully, National Institute of Allergy and Infectious Diseases, Bethesda, Md.; Acholeplasma modicum PG49 (= ATCC 29102), obtained from R. H. Leach, Mycoplasma Reference Laboratory, Central Public Health Laboratory, London, England; Acholeplasma oculi 19L (= ATCC 27350), obtained from J. J. Callis, Plum Island Animal Disease Center, Long Island, N.Y.; and Acholeplasma equifetale C112 (= ATCC 29724) and Acholeplasma hippikon C1 (= ATCC 29725), obtained from H. Kirchhoff, Institute für Mikrobiologie und Tierseuchen, Tierärztliche Hochschule Hannover, Hannover, West Germany.

Media. The acholeplasmas were cultivated in a medium containing seven parts of PPLO broth without crystal violet (Difco Laboratories, Detroit, Mich.), two parts of unheated horse serum, and one part of $25 \%$ (wt/wt) fresh yeast extract; this medium was supplemented with 1\% Phytone (BBL Microbiology Systems, Cockeysville, Md.) and $1 \%$ penicillin G $(100,000 \mathrm{U} / \mathrm{ml})$. A serum-free medium (the medium described above but without serum) was also used. Solid medium was prepared by adding $1.2 \%$ granulated agar (catalog no. 11849; BBL) to the liquid medium.

Morphological studies. Agar plates were incubated at both 30 and $37^{\circ} \mathrm{C}$ under aerobic conditions; 5-day-old colonies were observed with a stereomicroscope.

For electron microscopy, cells collected by centrifugation from 24-h-old serum-free broth cultures were fixed in a mixture containing $5 \%$ glutaraldehyde and $1 \%$ paraformaldehyde, postfixed in $1 \%$ osmium tetraoxide, and embedded in Epon 812. Ultrathin sections were stained with uranyl acetate and lead nitrate and were examined with a Hitachi HU-12 electron microscope.

Reversion experiments. The strains were subcultured five times in liquid medium without penicillin, and each culture was inoculated onto solid medium without bacterial inhibitors.

Filtration studies. Filtration tests were performed with 24-h-old cultures of strains $\mathrm{H} 7 \mathrm{M}$ and $\mathrm{H} 23 \mathrm{M}^{\mathrm{T}}$ grown in the serum-free medium. Filterability was determined by using a Swinny hypodermic adapter and membrane filters (Millipore Corp., Bedford, Mass.) with average pore diameters of $800,450,220$, and $100 \mathrm{~nm}$.

Sterol requirement. To determine the sterol requirements of the strains, the method of Razin and Tully (17) was used, except that growth was determined on solid medium by observing the development of colonies. To the serum-free basal medium bovine serum albumin $(5 \mathrm{mg} / \mathrm{ml})$, palmitic acid $(10 \mu \mathrm{g} / \mathrm{ml})$, and cholesterol $(0,1,5$, or $20 \mu \mathrm{g} / \mathrm{ml})$ were added. Susceptibility to $1.5 \%$ digitonin and $20 \%$ sodium polyanethol sulfonate was determined by the paper disk inhibition method described by Freundt et al. (7).

Growth conditions. Growth at 22,37 , and $45^{\circ} \mathrm{C}$ under aerobic or anaerobic $\left(5 \% \mathrm{CO}_{2}\right.$ in nitrogen gas) conditions was examined every other day for 10 days.

Biochemical tests. Biochemical tests were performed in both serum-supplemented and serum-free media. 
Tests for utilization of glucose, salicin, arginine, and urea were performed in medium containing $1 \%$ test substrate and $0.0017 \%$ phenol red. Esculin hydrolysis was determined by the method of Williams and Wittler (25). Tests for reduction of 2,3,5-triphenyltetrazolium chloride $(0.05 \%)$, methylene blue $(0.0001 \%$ ), and tellurite $(0.05 \%)$ were performed by the method of Aluotto et al. (3). Hemolysis was tested by the overlay method, using horse, sheep, and guinea pig erythrocytes (3).

Hexokinase activity. Hexokinase activity was determined in frozen and thawed cell suspensions by the method of Cirillo and Razin $(4,26)$, as follows. Cells in logarithmic phase were harvested from $1,000 \mathrm{ml}$ of a broth culture by centrifugation, washed twice in 0.25 $\mathrm{M} \mathrm{NaCl}$, and resuspended in the same solution at a concentration of approximately $10 \mathrm{mg}$ of cell protein per $\mathrm{ml}$. Protein concentrations were measured by the method of Lowry, using bovine serum albumin as the standard. Each reaction mixture contained $0.25 \mu \mathrm{mol}$ of $\mathrm{D}-\left[U_{-}{ }^{14} \mathrm{C}\right]$ glucose $\left(0.06 \mu \mathrm{Ci} / \mathrm{ml}\right.$; about $\left.10^{5} \mathrm{cpm}\right)$ $0.4 \mu \mathrm{mol}$ of adenosine triphosphate, $0.03 \mu \mathrm{mol}$ of $\mathrm{MgCl}_{2}, 0.8 \mu \mathrm{mol}$ of $\mathrm{NaF}, 8.0 \mu \mathrm{mol}$ of glycyl-glycine

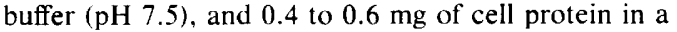
final volume of $0.25 \mathrm{ml}$. This mixture was incubated in a tube at $37^{\circ} \mathrm{C}$, and the reaction was stopped after 30 , 60 , and $90 \mathrm{~min}$ by adding $1 \mathrm{ml}$ of ice-cold, deionized water, followed by centrifugation. The supernatants were adsorbed to a column (lower diameter, $6 \mathrm{~mm}$; upper diameter, $8.5 \mathrm{~mm}$; length, $780 \mathrm{~mm}$ ) of Bio-Rad AG1-X2 anion exchange resin $\left(\mathrm{Cl}^{-}\right.$form; 50 to 100 mesh), free $\mathrm{D}-\left[U_{-}{ }^{14} \mathrm{C}\right]$ glucose was washed from the column with $25 \mathrm{ml}$ of deionized water, and the labeled products were eluted with $6 \mathrm{ml}$ of $1.0 \mathrm{M} \mathrm{LiCl}$. The eluate was mixed with scintillation liquor $[333 \mathrm{ml}$ of Triton X-100, $666 \mathrm{ml}$ of toluene, $5.5 \mathrm{~g}$ of 2,5-diphenyloxazole, $125 \mathrm{mg}$ of dimethyl-1,4-bis-2-(5-phenyloxazolyl)benzene] and counted with a Packard Tri-Carb liquid scintillation spectrometer. Radioactivity values were determined by correcting for the values obtained for parallel mixtures lacking adenosine triphosphate at zero time. Results were expressed as nanomoles of glucose phosphorylated per milligram of cell protein per minute. Hexokinase activities were also determined for A. laidlawii $\mathrm{PG}^{\mathrm{T}}$, A. granularum $\mathrm{BTS} 39^{\mathrm{T}}$,

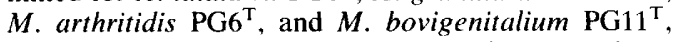
which were used as positive and negative controls.

Carotenoid pigments. The abilities of the organisms to synthesize carotenoid pigments were tested by using the procedure of Razin and Cleverdon (15). The organisms were grown in $500 \mathrm{ml}$ of the serum-free liquid medium described above supplemented with $0.5 \%$ sodium acetate. Carotenoid pigments were extracted from whole cells with $5 \mathrm{ml}$ of boiling ethanol. The amounts of carotenoid pigments present were expressed as absorbance at $438 \mathrm{~nm}$ per milligram of cell protein.

Peptone requirement. Portions $\left(0.1 \mathrm{ml} ; 10^{4}\right.$ colonyforming units [CFU] per $\mathrm{ml}$ ) of a 48 -h-old culture in serum-free medium of each isolate were inoculated onto peptone media. These peptone media contained $6.8 \mathrm{~g}$ of $\mathrm{NaCl}, 0.4 \mathrm{~g}$ of $\mathrm{KCl}, 0.2 \mathrm{~g}$ of $\mathrm{MgSO}_{4} \cdot 7 \mathrm{H}_{2} \mathrm{O}, 0.1$ $\mathrm{g}$ of $\mathrm{Na}_{2} \mathrm{HPO}_{4} \cdot 12 \mathrm{H}_{2} \mathrm{O}, 6.0 \mathrm{~g}$ of tris(hydroxymethyl)aminomethane, $2.5 \mathrm{mg}$ of nicotinic acid, $2.5 \mathrm{mg}$ of riboflavin, $12 \mathrm{~g}$ of Bacto-Agar (Difco), 20-g portions of various kinds of peptone (Phytone [BBL], Soytone [Difco], Bacto-Peptone [Difco], Difco Proteose Pep- tone no. 3, or tryptone [Difco]), and $1,000 \mathrm{ml}$ of distilled water, and the $\mathrm{pH}$ was adjusted to 7.8 with $\mathrm{HCl}$. The plates were incubated at $37^{\circ} \mathrm{C}$ for 2 weeks, and the number of CFU on each medium was determined.

Polyacrylamide gel electrophoresis of cell proteins. The polyacrylamide gel electrophoresis procedure described by Razin and Rottem (16) for determining cell proteins was used. Cell proteins were dissolved in phenol-acetic acid-water $(2: 1: 0.5, \mathrm{wt} / \mathrm{vol} / \mathrm{vol})$ and were run in polyacrylamide gels containing $5 \mathrm{M}$ urea and $35 \%$ acetic acid.

Determination of deoxyribonucleic acid base composition. Deoxyribonucleic acid was prepared by the method of Marmur (11), which was modified to include phenol extraction steps in place of the chloroformisoamyl alcohol deproteinization (19). The guanineplus-cytosine content of the deoxyribonucleic acid was determined by the method of Marmur and Doty (12), using an automatic recording spectrophotometer (Komatsu Electronics, Tokyo, Japan).

Serological techniques. Antisera against all of the type strains listed above except $A$. morum $72-043^{\mathrm{T}}$ were prepared in rabbits by a previously described procedure (27); antiserum to $A$. morum $72-043^{\mathrm{T}}$, was kindly supplied by J. G. Tully. The growth inhibition test was performed with filter paper disks by the method of Clyde (5). Each antigen was diluted 1:100 and $1: 1,000$ (containing about $10^{5}$ and $10^{4} \mathrm{CFU} / \mathrm{ml}$, respectively) in broth and then tested against undiluted antiserum. The indirect immunofluorescence technique with unfixed colonies was performed as described by Rosendal and Black (18).

\section{RESULTS}

Morphology and cultural characteristics. Colonies of strain $\mathrm{H} 23 \mathrm{M}^{\mathrm{T}}$ on media with and without horse serum after 5 days at 30 and $37^{\circ} \mathrm{C}$ are shown in Fig. 1. Colonies on serum-supplemented and serum-free media at $30^{\circ} \mathrm{C}$ exhibited a "fried-egg" shape, although colonies on serumfree medium were usually smaller; the colonies on media incubated at $37^{\circ} \mathrm{C}$ were of the rough type and had no peripheral zone. Strain $\mathrm{H} 23 \mathrm{M}^{\mathrm{T}}$ produced only slight turbidity in liquid medium. When they were examined by electron microscopy, cells from a 24-h-old broth culture of strain $\mathrm{H}_{23} \mathrm{M}^{\mathrm{T}}$ exhibited coccobacillary forms (Fig. 2). The cells were bounded by a single, triple-layered plasma membrane. A serum-free broth culture of strain $\mathrm{H}_{23} \mathrm{M}^{\mathrm{T}}$ containing $7 \times 10^{7}$ $\mathrm{CFU} / \mathrm{ml}$ was passed through filters with pore diameters of $800,450,220$, and $100 \mathrm{~nm}$, yielding $2 \times 10^{7}, 5 \times 10^{6}, 3.5 \times 10^{3}$, and $0 \mathrm{CFU} / \mathrm{ml}$, respectively. Similar results were obtained with strain H7M. When each strain was subcultured serially five times on a medium without bacterial inhibitors, there was no colonial or cultural evidence of reversion to bacterial forms.

Sterol requirement. All of the isolates grew on the basal medium, and they grew almost equally well on all of the media tested. They did not exhibit any growth response to increasing cho- 

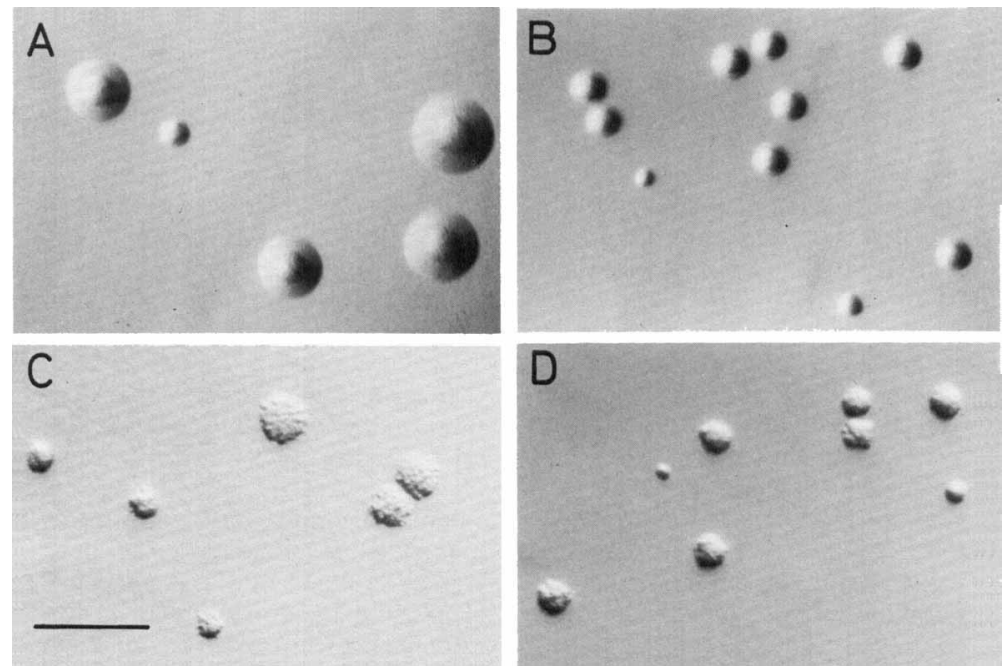

FIG. 1. Colonies of strain $\mathrm{H} 23 \mathrm{M}^{\mathrm{T}}$ on agar after 5 days. (A) Colonies on agar containing $20 \%$ horse serum at $30^{\circ} \mathrm{C}$. (B) Colonies on serum-free agar at $30^{\circ} \mathrm{C}$. (C) Colonies on agar containing $20 \%$ horse serum at $37^{\circ} \mathrm{C}$. (D) Colonies on serum-free agar at $37^{\circ} \mathrm{C}$. Bar $=200 \mu \mathrm{m}$.

lesterol concentrations in the medium. All of the isolates were resistant to $1.5 \%$ digitonin and $20 \%$ sodium polyanethol sulfonate.

Growth conditions. On media with and without serum, all of the isolates grew almost as rapidly at 22 as at $37^{\circ} \mathrm{C}$. They failed to grow at $45^{\circ} \mathrm{C}$. All of the isolates grew under both aerobic and anaerobic conditions.

Biochemical properties. None of the four strains fermented carbohydrates (including glucose, salicin, and esculin), hydrolyzed arginine or urea, or reduced tetrazolium chloride or methylene blue. All four strains reduced potassium tellurite and weakly hemolyzed horse, sheep, and guinea pig erythrocytes. After 14

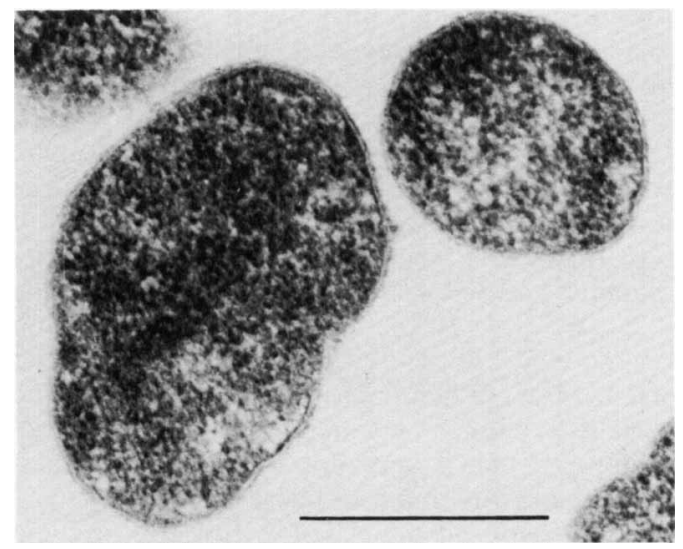

FIG. 2. Electron micrograph of a thin section of strain $\mathrm{H}_{23} \mathrm{M}^{\mathrm{T}}$ cells grown on serum-free medium for $24 \mathrm{~h}$ at $37^{\circ} \mathrm{C}$. Bar $=100 \mathrm{~nm}$. days of incubation in the medium containing glucose, the $\mathrm{pH}$ did not differ by more than $0.5 \mathrm{U}$ from the $\mathrm{pH}$ of the inoculated control in medium without glucose. In this test, the growth of the strains was confirmed by plate counts, and usually $10^{7}$ to $10^{8} \mathrm{CFU} / \mathrm{ml}$ was present in a 5 -dayold culture. No strain produced any appreciable $\mathrm{pH}$ change in the glucose-containing medium when the inoculum was increased 100 -fold or when the organism was serially subcultured up to 15 times in the glucose-containing medium. The type strains of eight currently recognized Acholeplasma species fermented glucose in the same test medium. In addition, the utilization of glucose was examined by determining hexokinase activity, which demonstrates the presence of the glycolytic pathway. The type strains of two glucose-fermenting Acholeplasma species, A. laidlawii and A. granularum, showed high hexokinase activity and phosphorylation of glucose, whereas the glucose-nonfermenting $M$. arthritidis and $M$. bovigenitalium strains tested had only low activities; the hexokinase activity of strain $\mathrm{H} 23 \mathrm{M}^{\mathrm{T}}$ was almost the same as the activities of the latter group (Table 1 and Fig. 3). Our results indicated that strain $\mathrm{H} 23 \mathrm{M}^{\mathrm{T}}$ does not ferment glucose.

Carotenoid pigments. Strain $\mathrm{H} 23 \mathrm{M}^{\mathrm{T}}$ and the type strains of A. axanthum, A. modicum, A. equifetale, and $A$. hippikon failed to produce carotenoid pigments, as determined by the method described above. The optical densities at $438 \mathrm{~nm}$ of the carotenoid pigments of $A$. laidlawii, A. granularum, and A. oculi were 57.3 $\times 10^{-3}, 36.9 \times 10^{-3}$, and $6.8 \times 10^{-3}$ per mg of protein, respectively. 
TABLE 1. Hexokinase activities of frozen and thawed cell preparations of selected members of the Mycoplasmatales

\begin{tabular}{|c|c|c|c|c|}
\hline \multirow[b]{2}{*}{ Strain } & \multirow{2}{*}{$\begin{array}{c}\text { Reaction } \\
\text { time at } \\
37^{\circ} \mathrm{C} \\
(\min )\end{array}$} & \multicolumn{3}{|c|}{ Amt of glucose phosphorylated } \\
\hline & & $\begin{array}{c}\mathrm{nmol} / \mathrm{mg} \text { of } \\
\text { protein }\end{array}$ & $\begin{array}{l}\mathrm{nmol} / \mathrm{mg} \text { of } \\
\mathrm{protein} \mathrm{per} \\
\mathrm{min}\end{array}$ & $\%$ \\
\hline \multirow[t]{3}{*}{ A. laidlawii $\mathrm{PG8}^{\mathrm{T}}$} & 30 & 538.5 & 17.95 & 80.0 \\
\hline & 60 & 555.5 & 9.26 & 82.6 \\
\hline & 90 & 521.6 & 5.80 & 77.6 \\
\hline \multirow{3}{*}{$\begin{array}{l}\text { A. granularum } \\
\text { BTS } 39^{\mathrm{T}}\end{array}$} & 30 & 425.2 & 14.17 & 60.0 \\
\hline & 60 & 491.8 & 8.20 & 69.4 \\
\hline & 90 & 504.8 & 5.61 & 71.2 \\
\hline \multirow[t]{3}{*}{ A. parvum $\mathrm{H} 23 \mathrm{M}^{\mathrm{T}}$} & 30 & 2.7 & 0.09 & 0.7 \\
\hline & 60 & 4.5 & 0.08 & 1.2 \\
\hline & 90 & 5.2 & 0.06 & 1.3 \\
\hline \multirow{3}{*}{$\begin{array}{l}M \text {. arthritidis } \\
\text { PG6 }^{\mathrm{T}}\end{array}$} & 30 & 1.3 & 0.043 & 0.3 \\
\hline & 60 & 1.9 & 0.034 & 0.5 \\
\hline & 90 & 5.9 & 0.062 & 1.5 \\
\hline \multirow{3}{*}{$\begin{array}{l}\text { M. bovigenitalium } \\
\text { PG11 }^{\mathrm{T}}\end{array}$} & 30 & 1.7 & 0.057 & 0.3 \\
\hline & 60 & 5.7 & 0.095 & 1.2 \\
\hline & 90 & 6.6 & 0.073 & 1.3 \\
\hline
\end{tabular}

Peptone requirement. The isolates grew best in Phytone- and Soytone-containing media, although the Acholeplasma type strains grew equally well in all of the peptone-containing media tested. With strain $\mathrm{H}_{23} \mathbf{M}^{\mathrm{T}}$, the number of CFU obtained per milliliter from cultures grown in the Phytone- and Soytone-containing media were usually 3 logs higher than the values obtained with the other peptone-containing media.

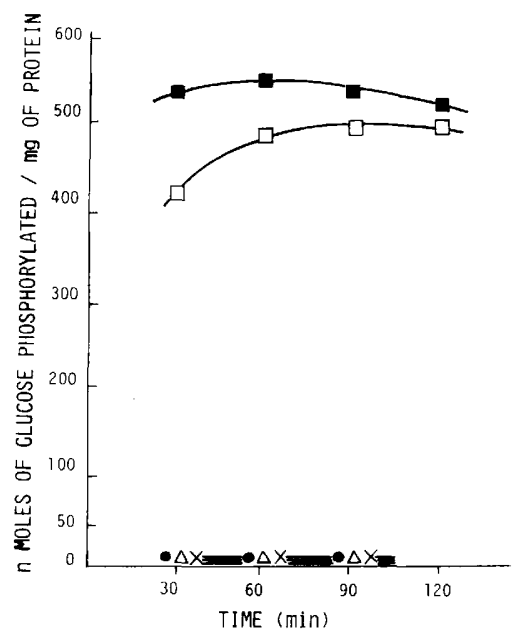

FIG. 3. Rates of phosphorylation of glucose by frozen and thawed cell preparations. Symbols: $\mathbf{\square}, A$. laidlawii $\mathrm{PG}^{\mathrm{T}}$; $\square, A$. granularum BTS $39^{\mathrm{T}} ;$ O $A$. parvum $\mathrm{H}_{23} \mathrm{M}^{\mathrm{T}} ; \triangle, M$. arthritidis $\mathrm{PG6}^{\mathrm{T}} ; \times, M$. bovigenitalium $\mathrm{PG} 11^{\mathrm{T}}$.
Electrophoretic patterns of cell proteins. The electrophoretic pattern of the cell proteins of strain $\mathrm{H} 23 \mathrm{M}^{\mathrm{T}}$ differed from the patterns of the type strains of Acholeplasma species (Fig. 4). Furthermore, the patterns of the type strains of the Acholeplasma species were distinct from one another.

Deoxyribonucleic acid base composition. The guanine-plus-cytosine content of the deoxyribonucleic acid of strain $\mathrm{H} 23 \mathrm{M}^{\mathrm{T}}$ was $29.1 \mathrm{~mol} \%$, as determined by the thermal melting point method, whereas the values obtained for $A$. laidlawii $\mathrm{PG}^{\mathrm{T}}$ and $A$. granularum BTS $39^{\mathrm{T}}$ were 30.4 and $29.8 \mathrm{~mol} \%$, respectively.

Serological properties. The four strains isolated from horses and the type strains of the Acholeplasma species were examined for antigenic relationships by reciprocal growth inhibition tests. None of the isolates showed a zone of growth inhibition around disks of antisera against the type strains of $A$. laidlawii, A. granularum, A. axanthum, A. modicum, A. oculi, $A$. equifetale, A. hippikon, and A. morum, and antiserum against strain $H 23 \mathrm{M}^{\mathrm{T}}$ inhibited only the four new isolates. However, there was slight inhibition of both $A$. modicum and $A$. morum by $A$. hippikon antiserum and of $A$. equifetale by both $A$. modicum and $A$. oculi antisera. In each of these instances, the zone of inhibition was less than one-half the size of the zone produced by the homologous antiserum. Stain $\mathrm{H} 23 \mathrm{M}^{\mathrm{T}}$ also differed from the type strains of the Acholeplasma species when it was tested by the indirect immunofluorescence method (Table 2). 


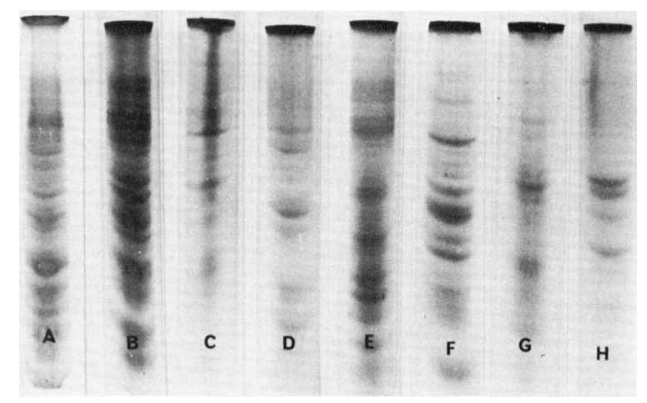

FIG. 4. Electrophoretic patterns of Acholeplasma cell proteins. Lane A, $A$. laidlawii $\mathrm{PG8}^{\mathrm{T}}$; lane B, $A$. granularum BTS $39^{\mathrm{T}}$; lane C, A. modicum PG49 ${ }^{\mathrm{T}}$; lane $\mathrm{D}$, A axanthum $\mathrm{S} 743^{\mathrm{T}}$; lane $\mathrm{E}$, A oculi $19 \mathrm{~L}^{\mathrm{T}}$; lane $\mathrm{F}$, A. equifetale $\mathrm{C}_{112}{ }^{\mathrm{T}}$; lane $\mathrm{G}, A$. hippikon $\mathrm{C}^{\mathrm{T}}$; lane $\mathrm{H}$, A. parvum $\mathrm{H}_{23} \mathrm{M}^{\mathrm{T}}$.

\section{DISCUSSION}

The isolates from horses were identified as members of the order Mycoplasmatales on the basis of morphology and passage through filters with a pore size of $220 \mathrm{~nm}$. These isolates were placed in the family Acholeplasmataceae because of their growth in media without cholesterol and their resistance to digitonin. Growth of the isolates at $22^{\circ} \mathrm{C}$ is also consistent with membership in Acholeplasmataceae. Moreover, fried-egg colonial morphology was obtained by incubation at $30^{\circ} \mathrm{C}$ but not by incubation at $37^{\circ} \mathrm{C}$, suggesting that the temperature for optimum growth is close to $30^{\circ} \mathrm{C}$. The probable host of these isolates has not been identified. Because other Acholeplasma species have been isolated from various hosts $(1,2,8-10,22,24)$, it is not reasonable at present to conclude that the horse is the specific habitat of the isolates described above. With respect to biological properties, the new isolates are clearly distinct from the eight currently recognized species of Acholeplasma (A. Iaidlawii, A. granularum, A. axanthum, A. modicum, A. oculi, A. equifetale, A. hippikon, and $A$. morum). The new isolates did not ferment any carbohydrate that was hydrolyzed by the other acholeplasmas, and their hexokinase activities were low, like the activities of the nonfermentative organisms $M$. arthritidis and $M$. bovigenitalium.

The International Commission on Systematic Bacteriology Taxonomic Subcommittee has indicated that the ability of an organism to synthesize carotenoid pigments should be determined if the organism is being considered for membership in the family Acholeplasmataceae (21). In our study, the absence of carotenoids in the horse isolates was indicated by the lack of appreciable adsorption of light waves at $438 \mathrm{~nm}$ by extracts of $500-\mathrm{ml}$ portions of broth cultures. Recently, Smith et al. have shown that $A$. $a x$ anthum (20) and $A$. modicum (13) can produce carotenoids when large volumes (yield from more than 50 liters) of cells and absorption at a shorter wavelength are used. If the same methods were used with the horse isolates, carotenoids might be detected also in these organisms.

Phytone and Soytone have significant effects on the growth of the isolates which we studied. The responses of the isolates to peptone indicated that these strains require an additional source of essential amino acids. However, it is difficult to determine the nutritional requirements of acholeplasmas. On initial isolation, A axanthum strains $S 743^{\mathrm{T}}$ and $\mathrm{S} 410$ were reported to require fatty acid supplements, in the form of Tween 80 , for adequate growth (23). Cells from later passages of these organisms did not appear to need additional fatty acids (6). A more specific test will be required to determine the growth responses of our isolates to peptone.

From the results described above, we conclude that strains $\mathrm{H} 23 \mathrm{M}^{\mathrm{T}}, \mathrm{H} 7 \mathrm{M}, \mathrm{H} 15 \mathrm{M}$, and $\mathrm{H} 23 \mathrm{~V}$ constitute a new species in the genus Acholeplasma. For this species we propose the name Acholeplasma parvum (par'vum. L. adj. parvus small, intended to refer to the poor

TABLE 2. Serological relationships of Acholeplasma strains, as determined by the indirect immunofluorescence test

\begin{tabular}{|c|c|c|c|c|c|c|c|c|c|}
\hline \multirow{2}{*}{ Strain } & \multicolumn{9}{|c|}{ Reciprocal indirect fluorescent antibody titer of rabbit antiserum against strain: } \\
\hline & $\mathrm{PG}^{\mathrm{T}}$ & BTS39 & $\mathrm{S} 743^{\mathrm{T}}$ & $\mathrm{PG} 49^{\mathrm{T}}$ & $19 L^{\mathrm{T}}$ & $\mathrm{C} 112^{\mathrm{T}}$ & $\mathrm{C} 1^{\mathrm{T}}$ & $72-043^{\mathrm{T}}$ & $\mathrm{H} 23 \mathrm{M}^{\mathrm{T}}$ \\
\hline A. laidlawii $\mathrm{PG8}^{\mathrm{T}}$ & 3,200 & - $^{a}$ & - & - & 200 & - & 200 & - & - \\
\hline A. granularum BTS39 & - & 3,200 & - & 400 & 100 & - & 200 & 100 & - \\
\hline A. axanthum $\mathrm{S} 743^{\mathrm{T}}$ & - & - & 3,200 & - & - & - & - & - & - \\
\hline A. modicum $\mathrm{PG}_{4} 9^{\mathrm{T}}$ & - & 一 & - & 3,200 & - & - & - & - & - \\
\hline A. oculi $19 \mathrm{~L}^{\mathrm{T}}$ & 400 & - & 100 & - & 3,200 & 200 & 200 & - & - \\
\hline A. equifetale $\mathrm{C} 112^{\mathrm{T}}$ & - & - & 100 & 一 & 400 & 3,200 & - & - & - \\
\hline A. hippikon $\mathrm{C} 1^{\mathrm{T}}$ & 200 & 一 & - & - & 200 & - & 6,400 & 200 & - \\
\hline A. morum $72-043^{\mathrm{T}}$ & 100 & 一 & - & 100 & 200 & 100 & 400 & 6,400 & - \\
\hline A. parvum $\mathrm{H} 23 \mathrm{M}^{\mathrm{T}}$ & - & - & - & - & 100 & - & - & - & 3,200 \\
\hline
\end{tabular}

${ }^{a} \ldots$, No fluorescence at a dilution of $1: 100$. 
biochemical activities and tiny colonies of this organism). Strain H23M is the type strain of $A$. parvum, and a culture of this strain has been deposited in the American Type Culture Collection as strain ATCC 29892.

\section{ACKNOWLEDGMENTS}

We thank S. Razin for helpful advice on preparation of the manuscript and N. Tanaka and T. Nishimura of The Institute of Applied Microbiology, University of Tokyo, Tokyo, Japan. for kind advice concerning the performance of the hexokinase test.

This work was supported by a grant from the Waksman Foundation of Japan, Inc.

\section{LITERATURE CITED}

1. Al-Aubaidi, J. M., and J. Fabricant. 1971. Characterization and classification of bovine mycoplasma. Cornell Vet. 61:490-518.

2. Allam, N. M., D. G. Powell, B. E. Andrews, and R. M. Lemcke. 1973. The isolation of Mycoplasma species from horses. Vet. Rec. 93:402.

3. Aluotto, B. B., R. G. Wittler, C. O. Williams, and J. E. Faber. 1970. Standardized bacteriologic techniques for characterization of Mycoplasma species. Int. J. Syst. Bacteriol. 20:35-58.

4. Cirillo, V. P., and S. Razin. 1973. Distribution of a phosphoenolpyruvate-dependent sugar phosphotransferase system in mycoplasma. J. Bacteriol. 113:212-217.

5. Clyde, W. A., Jr. 1964. Mycoplasma species identification based upon growth inhibition by specific antisera. J. Immunol. 92:958-965.

6. Edward, D. G. ff. 1971. Determination of sterol requirement for Mycoplasmatales. J. Gen. Microbiol. 69:205210 .

7. Freundt, E. A., B. E. Andrews, H. Ernø, M. Kunze, and F. T. Black. 1973. The sensitivity of Mycoplasmatales to sodium polyanethol sulfonate and digitonin. Zentralbl. Bakteriol. Parasitenkd. Infektionskr. Hyg. Abt. 1 Orig. Reihe A 225:104-112.

8. Gois, M., M. Cerny, V. Rozkosny, and M. Sovadina. 1969. Studies on the epizootiological significance of some species of Mycoplasma isolated from nasal swabs and lungs of pigs. Zentralbl. Veterinaermed. Reihe B 16:253-265.

9. Kirchhoff, H. 1978. Acholeplasma equifetale and Acholeplasma hippikon, two new species from aborted horse fetuses. Int. J. Syst. Bacteriol. 28:76-81.

10. Leach, R. H. 1967. Comparative studies of mycoplasma of bovine origin. Ann. N. Y. Acad. Sci. 143:305-316.

11. Marmur, J. 1961. A procedure for the isolation of deoxyribonucleic acid from microorganisms. J. Mol. Biol. 3:208-218.
12. Marmur, J., and P. Doty. 1962. Determination of the base composition of deoxyribonucleic acid from its thermal denaturation temperature. J. Mol. Biol. 5:109-118.

13. Mayberry, W. R., P. F. Smith, and T. A. Langworthy. 1974. Heptose-containing pentaglycosyl diglyceride among the lipids of Acholeplasma modicum. J. Bacteriol. 118:898-904

14. Ogata, M., J. Watabe, and K. Koshimizu. 1974. Classification of acholeplasmas isolated from horses. Jpn. J. Vet. Sci. 36:43-51.

15. Razin, S., and R. C. Cleverdon. 1965. Carotenoids and cholesterol in membranes of Mycoplasma laidlawii. J. Gen. Microbiol. 41:409-415.

16. Razin, S., and S. Rottem. 1967. Identification of Mycoplasma and other microorganisms by polyacrylamide gel electrophoresis of cell proteins. J. Bacteriol. 94:18071810.

17. Razin, S., and J. G. Tully. 1970. Cholesterol requirement of mycoplasmas. J. Bacteriol. 102:306-310.

18. Rosendal, S., and F. T. Black. 1972. Direct and indirect immunofluorescence of unfixed and fixed mycoplasma colonies. Acta Pathol. Microbiol. Scand. Sect. B 80:615622.

19. Saito, H., and K. Miura. 1963. Preparation of transforming deoxyribonucleic acid by phenol treatment. Biochim. Biophys. Acta 72:619-629.

20. Smith, P. F., and T. A. Langworthy. 1979. Existence of carotenoids in Acholeplasma axanthum. J. Bacteriol. 137:185-188.

21. Subcommittee on the Taxonomy of Mollicutes. 1979. Proposal of minimal standards for descriptions of new species of the Mollicutes. Int. J. Syst. Bacteriol. 29:172-180.

22. Tan, R. J. S., and J. A. R. Miles. 1972. Mycoplasma isolations from clinically normal cats. Br. Vet. J. 128:8790.

23. Tully, J. G., and S. Razin. 1969. Characteristics of a new sterol-nonrequiring Mycoplasma. J. Bacteriol. 98:970978.

24. Watabe, J., and M. Ogata. 1979. Studies on classification of acholeplasmas isolated from horses. cattle and abattoir sewage. Jpn. J. Vet. Sci. 41:9-17.

25. Williams, C. O., and R. G. Wittler. 1971. Hydrolysis of esculin and phosphatase production by members of the order Mycoplasmatales which do not require sterol. Int. J. Syst. Bacteriol. 21:73-77.

26. Working Group of the FAO/WHO Programme on Comparative Mycoplasmology. 1974. The determination of metabolism of glucose. World Health Organization Working Document $\mathrm{VPH} / \mathrm{MIC} / 74.2$. World Health Organization. Geneva.

27. Yamamoto, K., R. Harasawa, M. Ogata, T. Miura, and H. Nakane. 1976. Bacteriological examination of bovine pneumonic lungs in Japan. Jpn. J. Vet. Sci. 38:7-14. 